Jurnal Ekonomi Modernisasi

http://ejournal.unikama.ac.id/index.php/JEKO

JEM 12,2 (2016) 63-71

\title{
STRATEGI BERSAING JASA NON KLASIFIKASI PADA PT BIRO KLASIFIKASI INDONESIA
}

\author{
Aditya Wardhana \\ Program Studi Administrasi Bisnis, Fakultas Komunikasi dan Bisnis, Universitas Telkom \\ Jl. Telekomunikasi, No. 1, Bandung, Indonesia, 40257 \\ Budi Rustandi Kartawinata \\ Program Studi Administrasi Bisnis, Fakultas Komunikasi dan Bisnis, Universitas Telkom \\ Jl. Telekomunikasi, No. 1, Bandung, Indonesia, 40257 \\ Syahputra \\ Program Studi Administrasi Bisnis, Fakultas Komunikasi dan Bisnis, Universitas Telkom \\ Jl. Telekomunikasi, No. 1, Bandung, Indonesia, 40257
}

\begin{abstract}
The purpose of this study was to compete formulating global strategy PT Biro Klasifikasi Indonesia (BKI) in non-classification marine services business (independent assurance) in Indonesia that includes three business sector such as marine, industry, and energy. The methodology used the analytical descriptive method with techniques SWOT analysis. The number of population as many as 5.248 companies, the target population was the BKI non-classification customers (non-klas) or independent assurance in all three business sector susch as marine, industry, and energy. The determination of the total sample using Slovin formulas with the levels of trust $95 \%$ obtained the total sample as many as 400 respondents. The research results showed that based on a position map of non-classification services business, BKI was on strategic rapid growth. BKI increased the number of a new job, increased new consumer on the non-classification services (independent assurance) in all business sectors, and focused on the type of nonclassification service business certain having the the highest value income for BKI.
\end{abstract}

Keywords: independent assurance, swot analysis, marine

DOI : http://dx.doi.org/10.21067/jem.v12i2.1193

Diterima : April 2016; Direvisi: Mei 2016; Diterima : Juni 2016

\section{PENDAHULUAN}

Potensi pasar bisnis PT Biro Klasifikasi Indonesia (BKI) sebagai salah satu Badan Usaha Milik Negara (BUMN) yang bergerak dalam bisnis jasa klasifikasi kapal di Indonesia masih cukup besar dan banyak yang belum tergarap, sehingga mendorong perubahan strategi bisnisnya.

* Corresponding Author. adityawardhana@telkomuniversity.ac.id
Perubahan perlu dilakukan mengingat beberapa faktor pendorong utama seperti kinerja perekonomian Indonesia dengan pertumbuhan ekonomi tahun 2014 sebesar 5,8\%-6,1\%, inflasi 4,5\%-6\%, dan pertumbuhan industri 10,34\%.

Faktor pertumbuhan ekonomi juga di dukung masih berlakunya beberapa regulasi pemerintah terkait kelautan, perindustrian serta ESDM, dan kinerja BKI secara keseluruhan tahun 2009 - 
2013 menunjukkan kecenderungan yang sehat AAA.

PT. Biro Klasifikasi Indonesia memiliki dua bidang jasa yang agak berbeda namun masih berkaitan secara rantai bisnis. Jasa tersebut adalah jasa klasifikasi dan statutory, dan jasa nonklasifikasi (independent assurance). Ruang lingkup bisnis jasa nonklasifikasi atau non-klas (independent assurance) meliputi: (1). Independent assurance dalam bidang marine. Bisnis seputar indepedent assurance yang terkait dengan dengan industri perkapalan (kapal pelayaran atau kapal cargo) serta seluruh penunjang bisnis perkapalan seperti shipping \& angkutan (pelayaran), galangan, infrastruktur pendukung laut (pelabuhan, bongkar muat \& pergudangan, bea cukai), dan perikanan. (2). Independent assurance dalam bidang industri. Bisnis seputar indepedent assurance di industri kimia dasar, industri mesin dan logam dasar serta aneka industri. (3). Independent assurance dalam bidang energi. Bisnis seputar independent assurance yang industri migas, mineral, geothermal, dan renewable energy serta seluruh penunjang bisnis sektor energi tersebut seperti kontraktor pertambangan

Kompetensi bisnis terkait jasa nonklasifikasi BKI terbagi atas lima belas jenis layanan nonklasifikasi (independent assurance) untuk ketiga sektor bisnisnya yaitu marine, industri, dan energi yaitu: identifikasi \& survey, mapping, inspeksi, test, analisa laboratorium, assesment, verifikasi, monitoring, konsultansi, project management, sertifikasi, training, investigasi, supervisi, dan umum (manpower supply).

Berdasarkan uraian diatas maka penulis merasa perlu melakukan kajian strategi bersaing untuk meningkatkan pencapaian pendapatan dan pertumbuhan jasa nonklasifikasi. Tujuan dari penelitian ini adalah untuk memetakan posisi bersaing PT Biro Klasifikasi Indonesia dan merumuskan strategi yang tepat untuk bersaing pada posisi tersebut.

\section{TINJAUAN PUSTAKA}

Kuncoro (2006) mengemukakan bahwa analisis SWOT (Strength, Weakness, Opportunities, Threats) biasa digunakan untuk mengevaluasi kesempatan dan tantangan di lingkungan bisnis maupun pada lingkungan eksternal perusahaan.

Kuncoro (2006) mengemukakan bahwa manajer tingkat atas menggunakan SWOT untuk mendorong refleksi diri dan diskusi kelompok tentang bagaimana mengembangkan perusahaan dan posisinya untuk mencapai sukses. Untuk memudahkan dan melaksanakan analisis SWOT diperlukan matriks SWOT. Matriks SWOT akan mempermudah merumuskan berbagai strategi yang perlu dijalankan oleh suatu perusahaan. Matriks SWOT tersebut dibuat dengan cara mengelompokkan masing-masing problem unsur SWOT ke dalam tabel matriks sebagaimana tampak pada Tabel 1 .

Tabel 1.

Matriks Analisis SWOT

\begin{tabular}{|c|c|c|}
\hline & $\begin{array}{l}\text { STRENGTH (S) } \\
\text { Daftar semua } \\
\text { kekuatan yang } \\
\text { dimiliki. }\end{array}$ & $\begin{array}{l}\text { WEAKNESS } \\
\text { (W) } \\
\text { Daftar semua } \\
\text { kelemahan yang } \\
\text { dimiliki }\end{array}$ \\
\hline OPPORTUNITIES & Strategi SO & Strategi WO \\
\hline (0) & Gunakan semua & Atari semua \\
\hline $\begin{array}{l}\text { Daftar semua } \\
\text { peluang yang dapat } \\
\text { diidentifikasi. }\end{array}$ & $\begin{array}{l}\text { kekuatan yang } \\
\text { dimiliki untuk } \\
\text { memanfaatkan } \\
\text { peluang yang ada. }\end{array}$ & $\begin{array}{l}\text { kelemahan } \\
\text { dengan } \\
\text { memanfaatkan } \\
\text { semua peluang } \\
\text { yang ada. }\end{array}$ \\
\hline THREATS (T) & Strategi ST & Strategi WT \\
\hline Daftar semua & Gunakan semua & Tekan semua \\
\hline $\begin{array}{l}\text { ancaman yang dapat } \\
\text { diidentifikasi. }\end{array}$ & $\begin{array}{l}\text { kekuatan untuk } \\
\text { menghindar dari } \\
\text { semua ancaman. }\end{array}$ & $\begin{array}{l}\text { kelemahan dan } \\
\text { cegah semua } \\
\text { ancaman. }\end{array}$ \\
\hline
\end{tabular}

Sumber: Mudrajat (2006)

Pada dasarnya alternatif strategi yang diambil harus diarahkan pada usaha-usaha untuk menggunakan kekuatan dan memperbaiki kelemahan, memanfaatkan peluang-peluang bisnis serta mengantisipasi ancaman. Sehingga dari matriks SWOT tersebut akan diperoleh empat kelompok alternatif strategi yang disebut dengan strategi SO, strategi WO, strategi ST, dan strategi WT. 
Aditya, Budi, Syahputra, Strategi Bersaing Jasa....

Dengan matriks strategi tersebut kemudian dilakukan positioning (pemetaan posisi) untuk mengukur posisi perusahaan yang bersangkutan dalam pasar industri. Mengingat pengaruh aspek internal dan eksternal terhadap bisnis berbeda-beda, maka dalam melakukan positioning harus dilakukan pembobotan dari aspek-aspek tersebut. Caranya adalah dengan terlebih dahulu membuat prioritas, mulai dari aspek yang peling berpengaruh hingga ke aspek yang paling tidak berpengaruh. Setelah itu, tentukan prosentase bobotnya.

Selanjutnya setiap aspek yang telah diberi bobot tersebut dapat dinilai dengan menggunakan hasil identifikasi SWOT. Jika faktor kekuatan lebih besar pengaruhnya (dominan) dibandingkan dengan faktor kelemahan, maka suatu aspek internal dianggap kuat. Sebaliknya jika faktor kekuatan lebih kecil pengaruhnya dari faktor kelemahan, maka suatu aspek internal dinilai lemah. Jika faktor kekuatan relatif seimbang dengan faktor kelemahan, maka suatu aspek internal dinilai sedang. Jika faktor peluang suatu faktor eksternal lebih besar pengaruhnya (dominan) dibandingkan dengan faktor ancamannya, maka suatu aspek eksternal dinilai menarik. Sebaliknya jika faktor peluang lebih kecil pengaruhnya dari faktor ancamannya, maka suatu aspek eksternal dinilai tidak menarik. Jika faktor peluang relatif seimbang dengan faktor ancamannya, maka suatu aspek eksternal dinilai sedang. Setelah penetapan nilai dilakukan, dilakukan pemberian nilai atau skor untuk setiap aspek internal maupun eksternal. Setelah skor masing-masing aspek dikalikan dengan bobotnya, kemudian seluruh aspek internal dan eksternal dijumlahkan. Akhirnya diperoleh skor total untuk aspek internal dan skor total untuk aspek eksternal.

Berdasarkan hasil pemberian skor yang diperoleh tersebut, dapat dibuatkan grafik positioning, dimana sumbu vertikal menggambarkan total skor aspek eksternal dan sumbu horizontal menggambarkan total skor aspek internal. Angka koordinat kedua aspek tersebut menunjukkan posisi perusahaan yang bersangkutan. Kendati demikian, analisis SWOT memiliki keterbatasan yang antara lain yaitu kekuatan tidak selalu menjadi keunggulan, analisis SWOT terhadap lingkungan eksternal terlalu sempit, SWOT memberikan analisis pada kondisi statis dan tidak dinamis, dan SWOT terlalu menekankan pada strategi satu dimensi (Kuncoro, 2006).

Berdasarkan penelitian yang dilakukan oleh Jackson, Joshi, Erhardt (2003), Rizzo \& Kim (2005), Chang \& Huang (2006), Duarte, Ettkin, Helms, and Anderson (2006), Sherman, Rowley, \& Armandi (2007), Markovska, Taseska, Jordanov (2009), Koo, Koo, Liu, \& Tsui (2011), Agarwal, Grassl, \& Pahl (2012), He \& Liao (2012), Antony (2012), Corsi, Marinelli, and Sottini (2013), menyatakan bahwa manajemen strategi secara luas digunakan oleh berbagai perusahaan dalam menghadapi persaingan pasar. Proses manajemen strategi terdiri dari tiga tahapan yaitu: formulasi strategi, implementasi strategi, dan evaluasi strategi. Analisis SWOT merupakan metode yang dibangun untuk untuk merumuskan strategi. Analisis SWOT baik peluang dan acaman eksternal maupun kekuatan dan kelemahan internal perusahaan merupakan formulasi dan pengembangan strategi yang penting.

Chang \& Huang (2006) menyatakan bahwa metode analisis SWOT yang dikuantifikasi akan menyediakan data yang lebih rinci dan terkuantifikasi dalam melakukan analisis SWOT. Metode analisis SWOT yang dikuantifikasi mengadopsi konsep MultipleAttribute Decision Making (MADM).

Wickramasinghe \& Takano (2009) menyatakan bahwa suatu pendekatan sistematis dan analitis dalam perencanaan strategi pemasaran dapat mengkombinasikan matriks SWOT dan Analytic Hierarchy Process (AHP). Teknik SWOT menginvestigasi faktor-faktor internal dan eksternal. Kombinasi ini akan dapat menentukan secara analitis berbagai faktor yang menjadi prioritas dan membuatnya menjadi mudah diukur secara umum. Faktorfaktor SWOT yang menjadi prioritas digunakan untuk memformulasikan berbagai strategi perbaikan alternatif dengan menggunakan matriks SWOT. 
Corsi, Marinelli, and Sottini (2013), Helms \& Nixon (2010), dan Comana \& Ronen (2009) menyatakan bahwa analisis SWOT dapat digunakan dalam membangun strategi dengan mempertimbangkan peluang dan kekuatan potensial yang dimiliki yang berdampak pada kelemahan dan ancaman, namun tidak dapat melingkupi keseluruhan aspek-aspek yang mungkin dihadapi.

Novicevic, Harvey, Autry, and Bond III (2004) menyatakan bahwa berbagai domensi baru terkait dengan analisis SWOT disiapkan dalam menghadapi terjadinya inkonsistensi logis yang dihadapi oleh manajer pemasaran dalam mensintesis berbagai komponen SWOT. Dengan menampilkan SWOT sebagai fokus bagi praktisi, peneliti, dan konsultan, dapat mengetahui variabilitas dalam penerapan inti manajerial yang logis dalam kondisi strategis secara koheren dari prespektif dual intelligenceand-planning.

\section{METODE}

Penelitian ini memfokuskan pada berbagai aspek yang berkaitan dengan analisis SWOT. Penelitian ini akan melakukan analisis untuk mendapatkan penjelasan atas berbagai aspek SWOT dengan penjelasan deskriptif analitis, sehingga hasil penelitian ini dapat digunakan sebagai dasar dalam pembuatan sebuah keputusan strategik. Metode pengumpulan data yang digunakan adalah menggunakan data sekunder dan data primer dengan cara sebagai berikut:

1. Strategic exploratory meeting yaitu melakukan wawancara dengan Direksi dan jajaran manajemen, desk research, serta studi dokumen untuk memperoleh pemahaman mengenai visi, visi, strategi, lingkup aktivitas bisnis BKI, pandangan arah pengembangan bisnis kedepan, kondisi internal serta hambatan-hambatan dan isu-isu yang dihadapi.

2. Aligning stakeholders and business yaitu menggali keinginan dan harapan para stakeholders utama dan shareholder, menetapkan rambu-rambu bisnis dan organisasi yang perlu diperhatikan dalam penyusunan rencana jangka panjang, dengan cara wawancara, analisis data dan informasi yang dapat dikumpulkan dari BKI.

3. Formulating corporate strategy yaitu dengan melakukan analisis SWOT.

Jumlah anggota populasi sebesar 5.248 perusahaan, target populasi adalah pelanggan non-klasifikasi (non-klas) atau independent assurance pada ketiga sektor bisnis yaitu marine, industri, dan energi. Penentuan jumlah sampel menggunakan rumus Slovin dengan tingkat kepercayaan 95\% diperoleh jumlah sampel sebanyak 400 responden. Teknik pengambilan sampel menggunakan cluster random sampling. Pengumpulan data primer menggunakan kuesioner yang didistribusikan kepada para responden.

\section{HASIL DAN PEMBAHASAN}

Analisa SWOT Jasa Nonklasifikasi dapat diuraikan sebagaimana berikut:

Kekuatan (strength) jasa nonklasifikasi BKI :

1. BKI memiliki jaringan pelayanan di seluruh kota utama Indonesia

2. Memiliki berbagai surat penunjukan dari Ditjen. Migas, Kemenaker, Kemenhub, dll

3. BKI memiliki keunikan jasa inspeksi marine yang dominan dibandingkan perusahaan independent assurance lainnya

4. Berpengalaman di bidang usaha jasa teknik khususnya marine, migas dan industry

Kelemahan (weakness) jasa nonklasifikasi BKI:

1. BKI belum memaksimalkan layanan yang berbasis core competence dan new technology approach

2. BKI belum mengoptimalkan komunitas industri perkapalan, industri kimia, mesin dan logam dasar, aneka industri, dan industri migas, industri mineral dan batubara, industri panas bumi, dan renewable energy

3. BKI belum mengoptimalkan channel bisnis yang mengakibatkan masih ditemukannya kendala dalam pemenangan tender.

Peluang (opportunities) jasa nonklasifikasi BKI: 
1. Penunjukan BKI oleh Kementerian Perindustrian untuk proses SNI khususnya kepada kapal yang melakukan ocean going

2. BKI memberikan jasa layanan teknik dengan keunikan kompetensinya yang memunculkan peluang di bidang marine, industri, energi melalui peningkatan core competence dan new technology approach

3. BKI Non-Klasifikasi memiliki potensi peningkatan pendapatan dari circular authority layanan turunan klasifikasi dari BKI Klas

4. Terbukanya kerjasama pendidikan dan pelatihan profesi teknik dengan instansi lain.

Ancaman (treath) jasa nonklasifikasi BKI :

1. Pertumbuhan perusahaan sejenis baik lokal maupun asing yang memiliki core competence dan new technology approach menciptakan ancaman bagi bisnis BKI

2. Kekuatan jaringan bisnis perusahaan asing memberikan ancaman terhadap pertumbuhan bisnis BKI

Adanya rencana pengklasifikasian PJIT di lingkungan ESDM membatasi segmen pasar yang dapat dilayani oleh BKI (jika hal tersebut jadi dilaksanakan).

Posisi Perusahaan (Jasa Non

Klasifikasi) Berdasarkan Analisis SWOT sebagaimana tampak pada Gambar 1.

Gambar 1.

Posisi SWOT Jasa Non-Klasifikasi

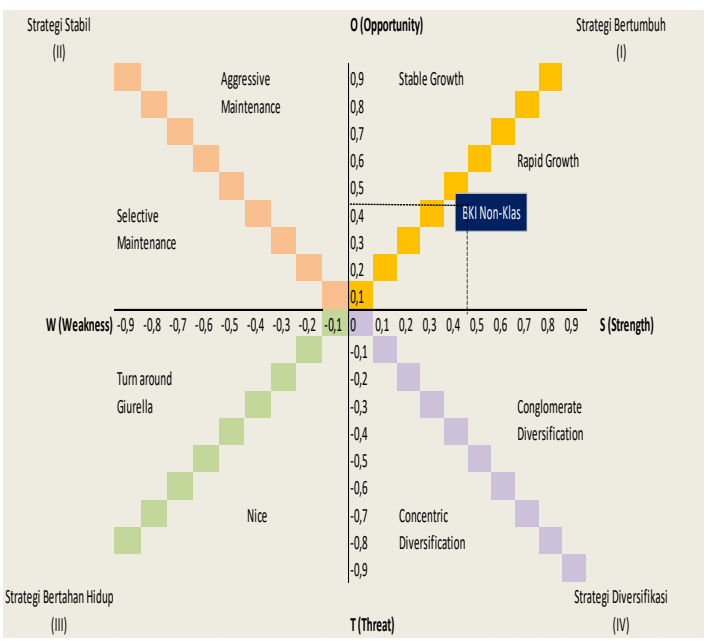

Sumber: Hasil Pengolahan Data, 2014
Dari analisa SWOT yang dilakukan, posisi SWOT Jasa Nonklasifikasi BKI pun berada pada kwadran I yaitu strategi pertumbuhan dengan kondisi pertumbuhan cepat (rapid growth). Oleh karena itu dengan peningkatan portofolio bisnis jasa non klasifikasi diharapkan akan makin meningkatkan pertumbuhan yang telah dicapai. Posisi kuadran I ini tercapai, dikarenakan adanya kekuatan nonklasifikasi yang besar, yaitu : (1) layanan sektor marine menjadi layanan unggulan dan menjadi keunikan dari layanan BKI yang ditopang core competence yang memadai, dan (2) bukti historis tingkat pertumbuhan pendapatan yang sangat pesat mencapai rata-rata $115 \%$ (dari tahun 2009 sampai dengan 2013). Sementara ancaman dan tantangannya relatif lebih kecil. Beberapa hal penting dalam analisa lingkungan usaha nonklasifikasi dapat dijabarkan sebagai berikut:

1. Dari sisi industrial forces, kompetitor dominan di Industri ini bisa disebutkan di antaranya : Sucofindo, Surveyor Indonesia dan Radiant Utama. Sedangkan keunggulan kompetitif mereka diantaranya adalah penguasaan teknologi terbaru, penawaran multi layanan, SDM yang berkualitas, serta standar layanan internasional. Fokus layanan segmen mereka, berkisar pada oil and gas, petrochemical, industrial, marine, mineral, manufacturing. Pendatang baru pada jasa ini, relatif cukup banyak dengan keunggulan kompetitif mereka pada pendekatan teknologi terbaru dan jaringan global (dunia), walaupun mereka memiliki entry barriers terutama pada harga yang relatif kompetitif. Pendatang baru ini pada umumnya memiliki cakupan segmen yaitu energi dan industri, dengan lebih fokus pada segmen energi.

2. Dari sisi market forces, beberapa isu pasar krusial yang mempengaruhi di antaranya adalah isu mengenai energi terbaharukan. Sedangkan dari sisi segmen pasar yang paling dominan adalah sektor marine, industri dan energi. Salah satu segmen pasar yang mengalami penurunan adalah pasar yang berkaitan dengan energi 
batubara, serta hasil tambang lainnya yang dikenai aturan pembatasan ekspor.

3. Dari sisi kebutuhan dan permintaan pasar, hal yang perlu mendapatkan perhatian berkenaan dengan jasa desain kapal yang menjadi layanan yang paling kurang memuaskan bagi pelanggan.

4. Dari sisi key trends, tren teknologi saat ini mengedepankan pada pendekatan metodologi dan teknologi terbaru, sedangkan dari sisi regulasi tren yang cukup mempengaruhi adalah keberlakuan pasar bebas yang mendorong pertumbuhan industri.

5. Dari sisi makro ekonomi, hal yang berkaitan dengan global market adalah krisis moneter yang berdampak pada penguatan kurs Dolar terhadap Rupiah. Sedangkan dari sisi infrastruktur ekonomi berkaitan dengan peningkatan pembangunan infrastruktur industri, energi dan marine.

Berdasarkan analisis pemetaan pasar jasa nonklasifikasi BKI dinyatakan bahwa dengan jasa independent assurance, dapat diidentifikasi bahwa jasa non klasifikasi ini memiliki potensi pelanggan dari pemerintah, BUMN, maupun swasta.

Dari keseluruhan pangsa pasar jasa nonklasifikasi diatas, pasar independent assurance di sektor marine yang cukup besar, yaitu 1,99 T (tahun 2013) dan diproyeksikan meningkat menjadi 3,787 $\mathrm{T}$ (tahun 2018). Independent assurance di pemerintah cukup besar potensinya, disusul oleh swasta.

Gambar 2.

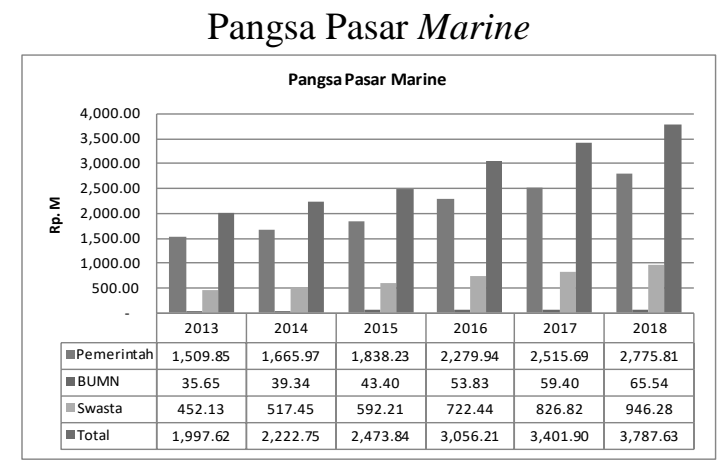

Sumber: Hasil Pengolahan Data, 2014
Beberapa contoh potensi pasar independent assurance sektor marine terkait laut:

1. Pekerjaan-pekerjaan 16 layanan Non Klas terkait investasi kapal dan kelautan di pemerintahan (Kemenhub, Kemen Perikanan dan Kelautan, Kemenperin, Militer)

2. Pekerjaan-pekerjaan 16 layanan Non Klas di BUMN terkait

3. Di swasta : turunan klas (dari shipowner yang sudah terdaftar di BKI), maupun dari luar data yang ada

Pangsa pasar independent assurance sektor industri berada paling banyak pada pelanggan swasta, dan pemerintah menempati porsi kedua. Nilai pangsa pasar pada tahun 2013 adalah 1,4 $\mathrm{T}$ rupiah. Dan pangsa ini diproyeksikan terus tumbuh menjadi 2,6 T rupiah di tahun 2018.

Gambar 3. Pangsa Pasar Industri

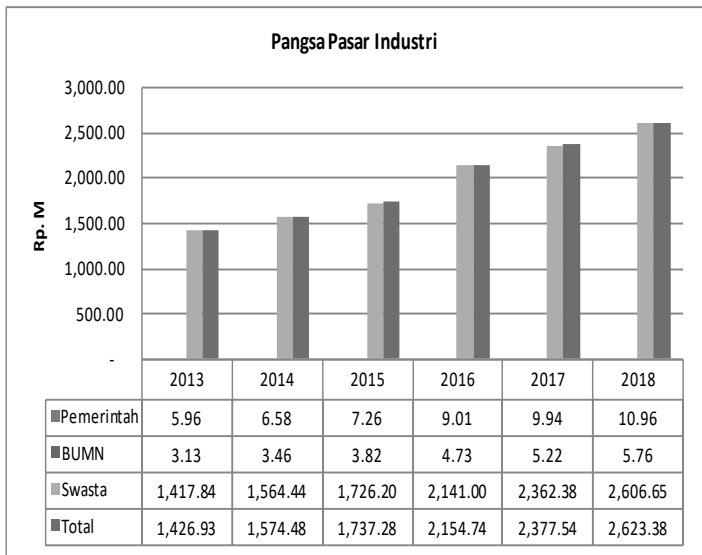

Sumber: Hasil Pengolahan Data, 2014

Beberapa contoh potensi pasar independent assurance sektor industri terkait laut :

1. Pekerjaan-pekerjaan 16 layanan Non Klas terkait produk industri di pemerintahan (Kemenperin, Kemendag)

2. Pekerjaan-pekerjaan 16 layanan Non Klas di BUMN terkait produk.

3. Di Swasta : turunan klas (dari turunan kegiatan material - komponen-industrial), maupun dari luar data yang ada. 
Pada sektor energi, kegiatan independent assurance juga memiliki pangsa pasar yang cukup besar. Independent assurance di sektor migas dan pertambangan umum menjadi sasaran pasar bisnis ini. Kegiatan cost recovery di sektor migas, investasi di pertambangan umum, dan investasi di migas, yang ketiganya memerlukan kegiatan independent assurance yang cukup siginifikan.

Di tahun 2013, pangsa pasar independent assurance di sektor energi terkait laut sebesar 1,353 T. Dan ini diproyeksikan meningkat terus di tahun 2018 menjadi 1,95 $\mathrm{T}$ rupiah. Beberapa contoh potensi pasar independent assurance sektor energi terkait kelautan:

1. Pekerjaan-pekerjaan 16 layanan non klasifikasi terkait energi di pemerintahan (Kemen ESDM, Kemenperin)

2. Pekerjaan-pekerjaan 16 layanan Non Klas di BUMN terkait energi (Pertamina, PLN, PGN) .

3. Di swasta : pertambangan umum, migas

Gambar 4.

Pangsa Pasar Energi

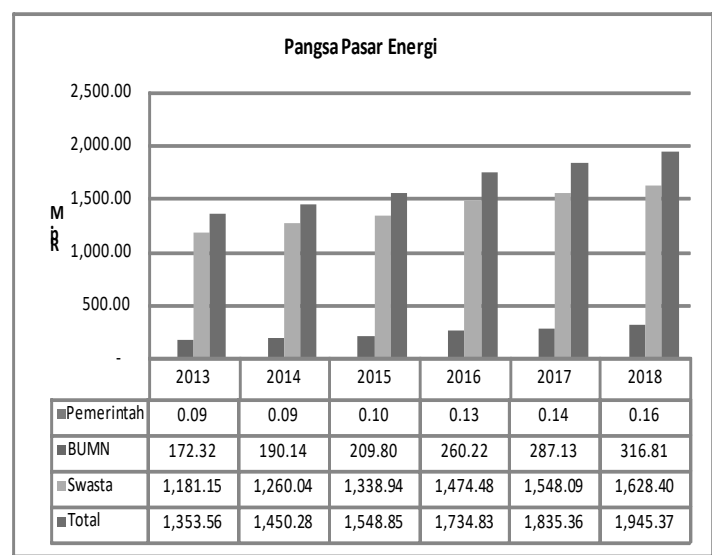

Sumber: Hasil Pengolahan Data, 2014

Berdasarkan analisis pemetaan pesaing jasa nonklasifikasi dinyatakan bahwa pada jasa independent assurance (nonklasifikasi) ini, BKI memiliki pesaing kuat nasional adalah Sucofindo, Radiant Utama dan Surveyor Indonesia. Dari kespesifikan layanan terkait marine, BKI NonkKlasifikasi-lah yang kuat, meski secara omset BKI belum menjadi nomor 1 di antara ketiganya. Pada Sucofindo, Radiant
Utama dan Surveyor Indonesia, jasa independent assurance hanya merupakan sebagian kecil dari bisnis mereka. Sehingga fokus mereka pada bisnis ini menjadi tidak besar. Ini menjadi peluang bagi BKI nonklasifikasi untuk menguasai pasar jasa independent assurance terkait kelautan ini. Mengingat entry barier bisnis jasa independent assurance ini cukup mudah, selain tiga perusahaan besar di atas, terdapat sekitar 460 perusahaan yang bergerak pada bisnis independent assurance ini. Meski demikian, sekitar 460 perusahaan ini tidak fokus pada area terkait laut. Ini juga menjadi peluang dan kekuatan BKI Nonklasifikasi ke depan. Dari seluruh peta persaingan di bisnis Nonklasifikasi ini, jika dipetakan menurut pangsa pasar, variasi layanan, sektor/ bidang layanan (untuk wilayah Indonesia), area geografis yang dilingkupinya, maka posisi BKI adalah sebagaimana berikut:

1. Dilihat dari penguasaan pangsa pasar: BKI masih termasuk perusahaan yang memiliki pangsa pasar terbesar.

2. Dilihat dari variasi layanan: BKI juga memiliki rentang variasi layanan yang jauh lebih luas dibandingkan pesaing-pesaing utamanya, seperti Sucofindo, Surveyor Indonesia, dan Radiant Utama.

3. Dari bidang pekerjaannya: dibandingkan dengan pesaing tedekatnya seperti Sucofindo dan Surveyor Indonesia, sektor atau bidang pekerjaan BKI jauh lebih fokus, sedangkan dibandingkan dengan salah satu utama lainnya yaitu Radiant, Sektor atau bidang pekerjaan BKI relatif sedikit lebih besar.

4. Dari cakupan pasar atau area geografis, BKI, Sucofindo dan Surveyor Indonesia relatif hampir memiliki cakupan area yang sama besar. Sedangkan Radiant cakupan area geografisnya jauh lebih kecil dibanding ketiga perusahaan tersebut.

Strategi Strength-Opportunities (SO) dapat dirumuskan yaitu penerbitan kebijakan wajib sertifikasi FPSO \& peralatannya, pendelegasian otorisasi yang lebih besar kepada $\mathrm{BKI}$, dan membangun sistem integrasi dengan 
Kemenhub dan Pelabuhan dalam memonitor kapal-kapal.

Strategi Weakness-Opportunities (WO) dapat dirumuskan yaitu peningkatan kuantitas dan kualitas SDM sesuai standar IACS, peningkatan investasi peralatan yang menudukung core business BKI, peningkatan penguasaan pasar pelanggan, dan optimalisasi media promosi.

Strategi Strength-Treath (ST) dapat dirumuskan yaitu meningkatkan customer value yang lebih besar daripada pesaing melalui kualitas layanan prima, CRM, tarif layanan yang kompetitif, dan membangun kedekatan yang intensif dengan pemerintah.

Strategi Weakness-Treath (WT) dapat dirumuskan yaitu meningkatkan keunggulan daya saing dengan meningkatkan kompetensi sesuai dengan standar internasional, mencari potential client, promosi yang lebih efektif, dan kemitraan.

\section{SIMPULAN}

Hasil penelitian menunjukkan bahwa posisi bisnis jasa nonklasifikasi BKI berada pada strategi pertumbuhan dengan kondisi pertumbuhan cepat. Posisi ini tercapai, dikarenakan adanya kekuatan nonklasifikasi yang besar, yaitu : (1) layanan sektor marine menjadi layanan unggulan dan menjadi keunikan dari layanan BKI yang ditopang core competence yang memadai, dan (2) bukti historis tingkat pertumbuhan pendapatan yang sangat pesat mencapai rata-rata $115 \%$ (dari tahun 2009 sampai dengan 2013). Strategi yang dibangun dalam bidang-bidang yaitu: bidang pemasaran, bidang keuangan, bidang sumber daya manusia, dan bidang operasi.

\section{SARAN}

BKI dapat meningkatkan jumlah pekerjaan baru dan konsumen baru layanan independent assurance marine (non klasifikasi) pada ketiga sektor yaitu marine, industri, dan energi, serta fokus pada jenis layanan bisnis non-klasifikasi tertentu yang memiliki nilai pendapatan yang tertinggi bagi BKI.

\section{DAFTAR PUSTAKA}

Agarwal, R., Grassl, W., \& Pahl, J. 2012. MetaSWOT: Introducing A New Strategic Planning Tool. Journal of Business Strategy, 33(2), pp. 12-21.

Antony, J. 2012. A SWOT Analysis on Six Sigma: Some Perspectives from Leading Academics and Practitioners. International Journal of Productivity and Performance Management, 61(6), pp. 691-698.

Chang, H., \& Huang W. 2006. Application of A Quantification SWOT Analytical Method. Mathematical \& Computer Modelling, 43, pp. 158-169.

Comana, A., and Ronen, B. 2009. Focused SWOT: Diagnosing Critical Strengths and Weaknesses. International Journal of Production Research, 47(20), pp. 5677 5689.

Corsi, A.M., Marinelli, N., and Sottini, V.A. 2013. Italian Wines and Asia: Policy Scenarios and Competitive Dynamics. British Food Journal, 115(3), pp. 342364

Duarte, C., Ettkin, L.P., Helms, M., Anderson,M.S. 2006. The Challenge of Venezuela: A SWOT Analysis. Competitiveness Review, 16(3/4), pp. 233-247

Jackson, S.E., Joshi, A., Erhardt, N.L. 2003. Recent Research on Team and Organizational Diversity: SWOT Analysis and Implications. Journal of Management, 29(6), pp. 801-830.

He, L., \& Liao, D. 2012. Credit NGOs' Sustainability in Rural Financial Market: A SWOT Analysis on DAYBANG. Humanomics, 28(3), pp. 200-208.

Helms, M., \& Nixon, J. 2010. Exploring SWOT Analysis - Where are We Now?: A Review of Academic Research from The Last Decade. Journal of Strategy and Management, 3(3), pp. 215-251.

Koo, H., Chau, J., Koo, L., Liu, S. \& Tsui, S. 2011. A structured SWOT Approach to Develop Strategies for The Government 
of Macau, SAR. Journal of Strategy and Management, 4(1), pp. 62-81.

Kuncoro, M. 2006. Strategi: Bagaimana Meraih Keunggulan Kompetetif. Jakarta: Erlangga.

Markovska, N., Taseska, V., Jordanov, P. 2009. SWOT Analyses of The National Energy Sector for Sustainable Energy Development. Energy, 34, pp. 752-756.

Novicevic, M., Harvey, M., Autry, C., Bond III, E. 2004. Dual-perspective SWOT: A Synthesis of Marketing Intelligence and Planning. Marketing Intelligence \& Planning, 22(1), pp. 84-94.

Rizzo, A., \& Kim, G.J. 2005. A SWOT Analysis of the Field of Virtual Reality Rehabilitation and Therapy. Presence, 14(2), pp. 119-146.

Sherman, H., Rowley, D.J., Armandi, B.R. 2007. Developing A Strategic Profile: The Pre-Planning Phase of Strategic Management. Business Strategy Series, 8(3), pp. 162-171.

Wickramasinghe, V., \& Takano, S. 2009. Application of Combined SWOT and Analytic Hierarchy Process (AHP) for Tourism Revival Strategic Marketing Planning: A Case of Sri Lanka Tourism. Journal of the Eastern Asia Society for Transportation Studies, 8, pp. 1-16. 